\title{
Drying Characteristics of Pointed Gourd Slices
}

\author{
Nisha Kumari* and Pratibha Devi Sharma \\ Department of Processing and Food Engineering, CAE, DRPCAU, PUSA (Samastipur) \\ Bihar - 848125, India \\ *Corresponding author
}

\section{A B S T R A C T}

\section{Keywords \\ Pointed gourd, Blanching, Moisture content, Drying time \\ Article Info \\ Accepted: \\ 15 September 2018 \\ Available Online: \\ 10 October 2018}

Pointed gourd (Trichosanthes dioica) is an important vegetable available seasonally. Pointed gourd slices were dried after pre-treatment using a tray dryer. To accomplish this process, raw, osmosed and blanched slices of pointed gourd were subjected to the drying air temperature of 50,60 and $70^{\circ} \mathrm{C}$ in a tray dryer. The drying time of osmosed sample was reduced to 480 minutes as compared to 600 and 840 minutes taken by blanched and raw pointed gourd samples. Drying of osmosed pointed gourd samples at $60^{\circ} \mathrm{C}$ drying air temperature provided shortest drying time to produce best quality dried product at final moisture content $7.47 \%$ wb compared to blanched and raw pointed gourd samples.

\section{Introduction}

Pointed gourd is the cucurbitaceous vegetable with high nutritive and medicinal value. In India the crop is commonly cultivated in the states of Bihar, Uttar Pradesh, Assam and West Bengal (Nath and Subramanyam, 1972).

The fruit show some prospects of use in the control of certain cancer like conditions (Som et al., 1993).

It is known as "king of gourds" because of its high nutrient content and medicinal value (Saha et al., 2004).

Under ordinary storage conditions, pointed gourd has a very short shelf life of 3-4 days.
Depletion of chlorophyll takes place very fast in ambient condition, which results in yellowing of the skin and the pulp which are least accepted and rejected by buyers in the market place (Koley et al., 2009).

\section{Materials and Methods}

\section{Sample preparation}

The fresh and good quality (tender) Swarnarekha variety pointed gourds were procured from local market of Pusa. They were properly washed in running water and wiped with blotting paper. Pointed gourds were cut into discs of size approximately (30 $\mathrm{mm}$ diameter and $4 \mathrm{~mm}$ thickness). 


\section{Determination of moisture content}

The moisture content of the untreated, osmotically treated, blanched and osmo- air dried pointed gourd samples was determined using the standard hot air oven method. Samples $(20 \mathrm{~g})$ were dried in the hot air oven at $102 \pm 2{ }^{\circ} \mathrm{C}$ for 24 hours (AOAC, 1990).

Moisture content $\left(\mathrm{MC}_{\mathrm{W}}\right)$ was determined on wet basis as:

$M C_{w}=\frac{W_{m}}{W_{m}+W_{d}} \times 100$

Where,

$M C_{W}=$ Moisture content on wet basis, (percent)

$W_{d}=$ Bone dry weight, $(\mathrm{g})$

$W_{m}=$ Moisture evaporated, $(\mathrm{g})$

\section{Osmotic dehydration of pointed gourd}

Osmotic dehydration of pointed gourd discs was carried out prior to tray drying using salt as a solute. The experimental design was made with the independent and dependent osmotic processing variables as per review of the previous research work on osmotic dehydration of vegetables and fruits and a few initial trials on the pointed gourd samples. The solution to product ratio (SPR) was kept fixed at $5: 1$.

\section{Blanching of pointed gourd}

Blanching of pointed gourd samples was carried out using the method as described by Sharma and Shrivastava (2017). Pointed gourd disc samples were blanched in water at $90^{\circ} \mathrm{C}$ for 2 minutes. After blanching, the samples were taken away from the boiling pan and left for cooling (15 to 20 minutes) before removing the excess water, by passing it through steel strainer. Besides, the pointed gourd discs were wiped with a cotton cloth to remove the surface moisture present.

\section{Drying of pointed gourd discs}

The drying operation was performed with the independent and dependent parameters/variables to study the drying characteristics of different types of pointed gourd samples. Pointed gourd discs were dried in a laboratory tray dryer. The drying of untreated, blanched and selected optimized osmotic pointed gourd samples was carried out in tray dryer separately with $400 \mathrm{~g}$ sample each. The temperature of the dryer was set and fixed at three temperatures- $50^{\circ} \mathrm{C}, 60^{\circ} \mathrm{C}$ and $70^{\circ} \mathrm{C}$ for different drying runs which were replicated thrice. Between each time intervals, the samples were taken out one by one without replacement and their final weight was measured using an electronic balance. All experiments were carried out at above mentioned three temperatures. Pointed gourd samples were dried until equilibrium was reached.

Moisture reduction, (percent, w.b.) was calculated using the formula:

$W_{m}=\left\{1-\frac{w_{i}}{w_{t}}(1-\mathrm{M})\right\} \times 100(2)$

Where,

$W_{m}=$ Moisture reduction, (percent, $\mathrm{wb}$ )

$w_{i}=$ Initial sample weight. $\mathrm{g}$

$w_{t}=$ Sample weight at any time, $\mathrm{g}$

$M=$ Initial moisture content in decimal

Bone dry material $\left(\mathrm{W}_{\mathrm{bd}}\right)$ in the sample was determined by the following formula:

$W_{b d}=\frac{100}{100+M C(d b \% 6)} \times W_{1}$

Drying rate (DR) was calculated using the following formula: 
$\mathrm{DR}=\frac{\text { Amount of moisture removed }}{\text { Time taken } \times \mathrm{W}_{\mathrm{bd}}}$

Where,

Amount of Moisture Removed $(\mathrm{g})=\mathrm{wi}-\mathrm{w}_{\mathrm{t}}$ (5)

DR = Drying rate $\left(^{\frac{\text { Kgwater }}{\text { Kgdm.h }} \times} 10^{-3}\right)$

$\mathrm{w}_{\mathrm{i}}=$ Initial sample weight, $(\mathrm{g})$

$\mathrm{w}_{\mathrm{t}}=$ Sample weight at any time, $(\mathrm{g})$

Time taken is equal to the interval of time between $\mathrm{w}_{\mathrm{i}}$ and $\mathrm{w}_{\mathrm{t}}$, in hour

\section{Rehydration characteristics}

The rehydration quality characteristics of dehydrated pointed gourd samples were determined by rehydration test (Ranganna, 1986). Dehydrated samples of $10 \mathrm{~g}$ each were placed with $200 \mathrm{ml}$ distilled water in glass beakers and were heated in water bath at $60^{\circ} \mathrm{C}$ for $60 \mathrm{~min}$. The excess water was drained off through filter paper (Whatman No. 4).

The drained samples were weighed on an electronic balance.

Rehydration ratio $\left(\mathrm{R}_{\mathrm{r}}\right)$ can be calculated from (Ranganna, 1986):

$\mathrm{R}_{\mathrm{r}}=\frac{C}{D}(6)$

Where,

$\mathrm{C}=$ Drained weight of the rehydrated sample, $\mathrm{g}$

$\mathrm{D}=$ Weight of dehydrated samples taken for rehydration test, $\mathrm{g}$

The coefficient of rehydration $\left(\mathrm{C}_{\mathrm{r}}\right)$, was computed using the equation (Ranganna, 1986).
$\mathrm{C}_{\mathrm{r}}=\frac{\mathrm{Cx}(100-\mathrm{A})}{\left(\mathrm{D}-\frac{\mathrm{BD}}{100}\right) \times 100}$

Where,

m.c. = Moisture content of rehydrated samples, percent (w.b.)

$\mathrm{A}=$ Moisture content of samples before dehydration, percent (w.b.)

$\mathrm{B}=$ Moisture content of the dehydrated sample, percent (w.b.)

$\mathrm{C}=$ Drained weight of the rehydrated sample, $\mathrm{g}$

$\mathrm{D}=$ Weight of dehydrated samples taken for rehydration test, $\mathrm{g}$

\section{Results and Discussion}

\section{Drying characteristics}

The moisture content at a different time interval (elapsed time) for tray drying of pointed gourd disc samples at different drying temperatures was analyzed. It was clear that as the drying air temperature increased, the reduction in moisture or weight loss also increased for all the treatments. The higher temperature of drying helps to reduce the time required to dry the discs up to equilibrium moisture content. Table 3 shows that it took 1020, 720 and 540 minutes time to reach the moisture content of 9.21, 9.62 and $8.24 \%$ for raw, blanched and osmosed sample respectively at drying air temperature of $50^{\circ} \mathrm{C}$. It took 840,600 and 480 minutes to reach the moisture content level of 7.70, 7.50 and $7.47 \%$ raw, blanched and osmosed sample respectively at drying air temperature of $60^{\circ} \mathrm{C}$. It also took 600, 540 and 360 minutes to reach the moisture content level of $6.82,6.96$ and $6.91 \%$ for raw, blanched and osmosed sample respectively at drying air temperature of $70^{\circ} \mathrm{C}$ (Fig. 1-4 and Table 1-3). 
Fig.1 View of different types of dehydrated pointed gourd discs at different drying air temperatures



Raw

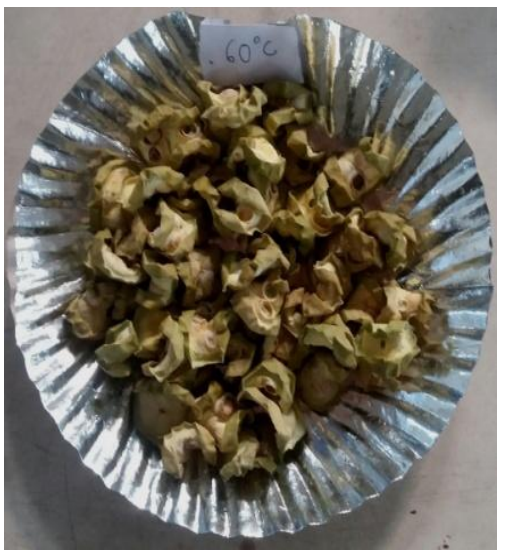

Raw

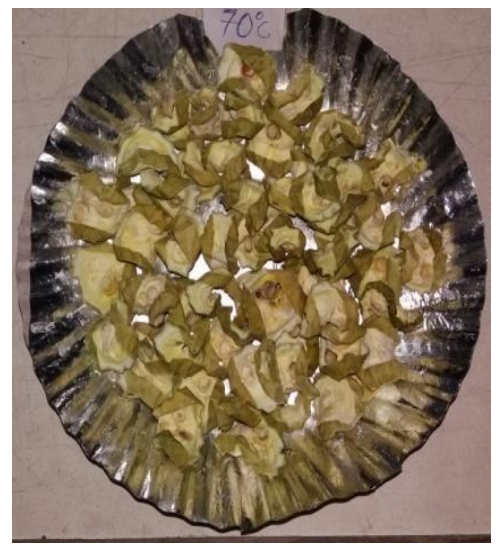

Raw

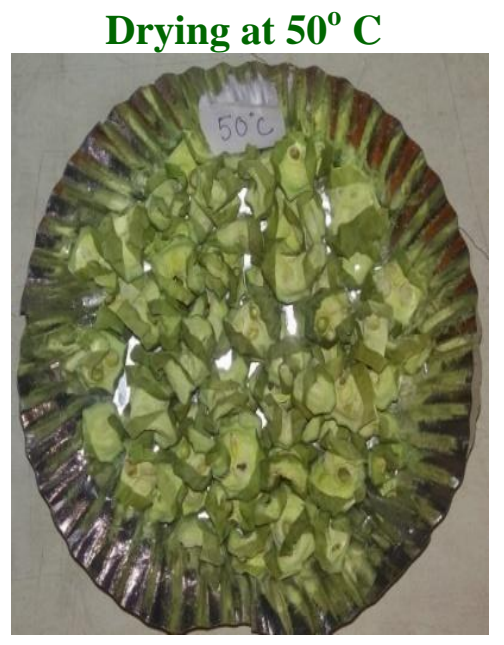

Blanched

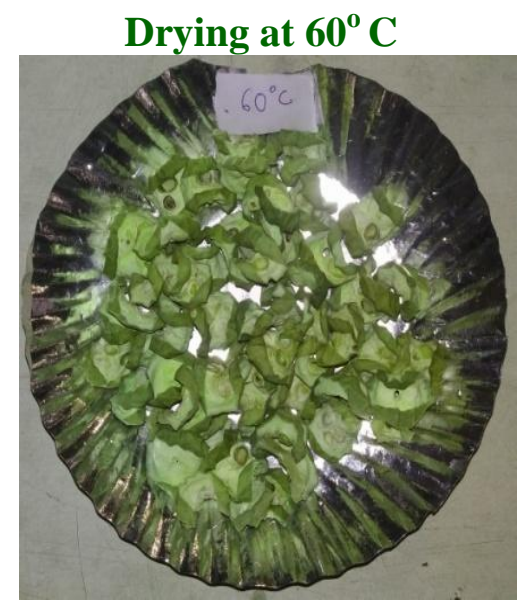

Blanched

Drying at $70^{\circ} \mathrm{C}$

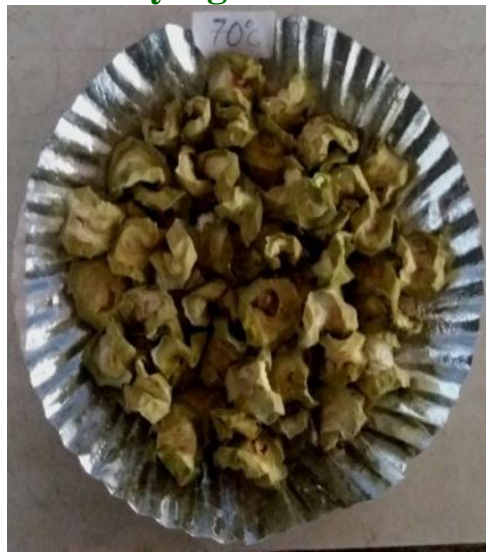

Blanched

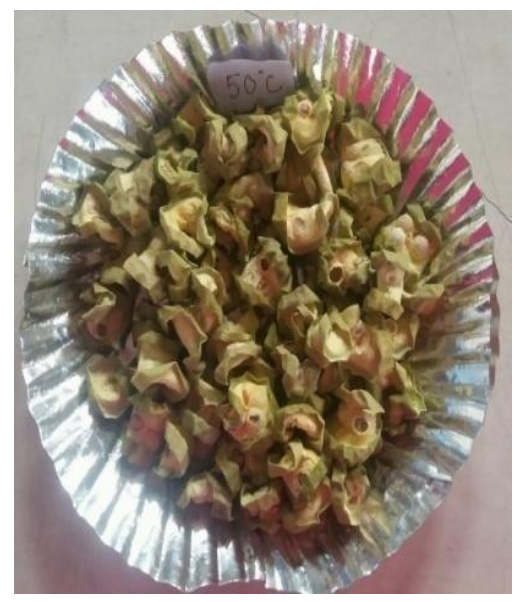

Osmosed

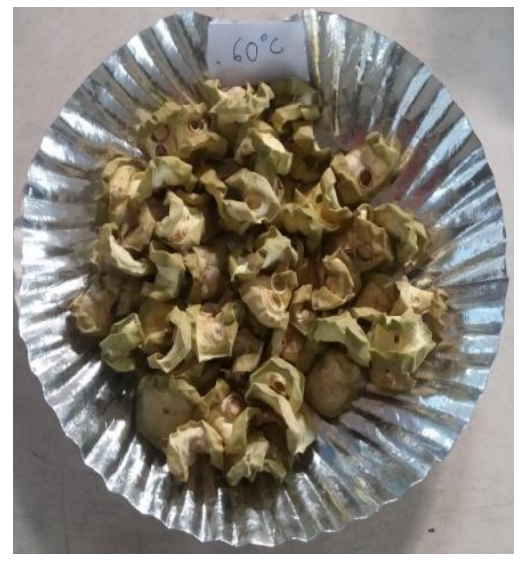

Osmosed

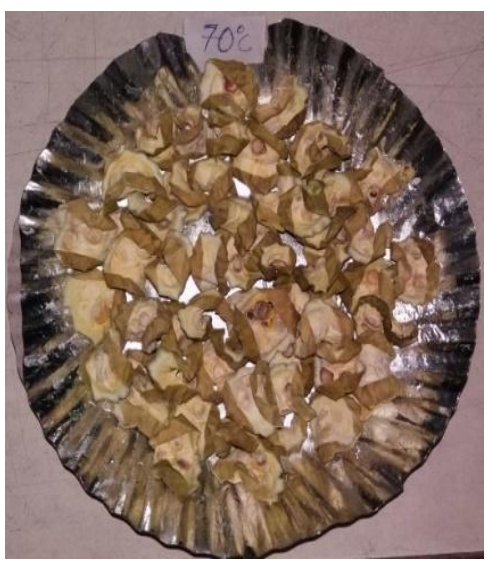

Osmosed 
Fig.2 Variation in drying rate of raw pointed gourd discs with average moisture content (\%, w.b.) at different drying air temperatures
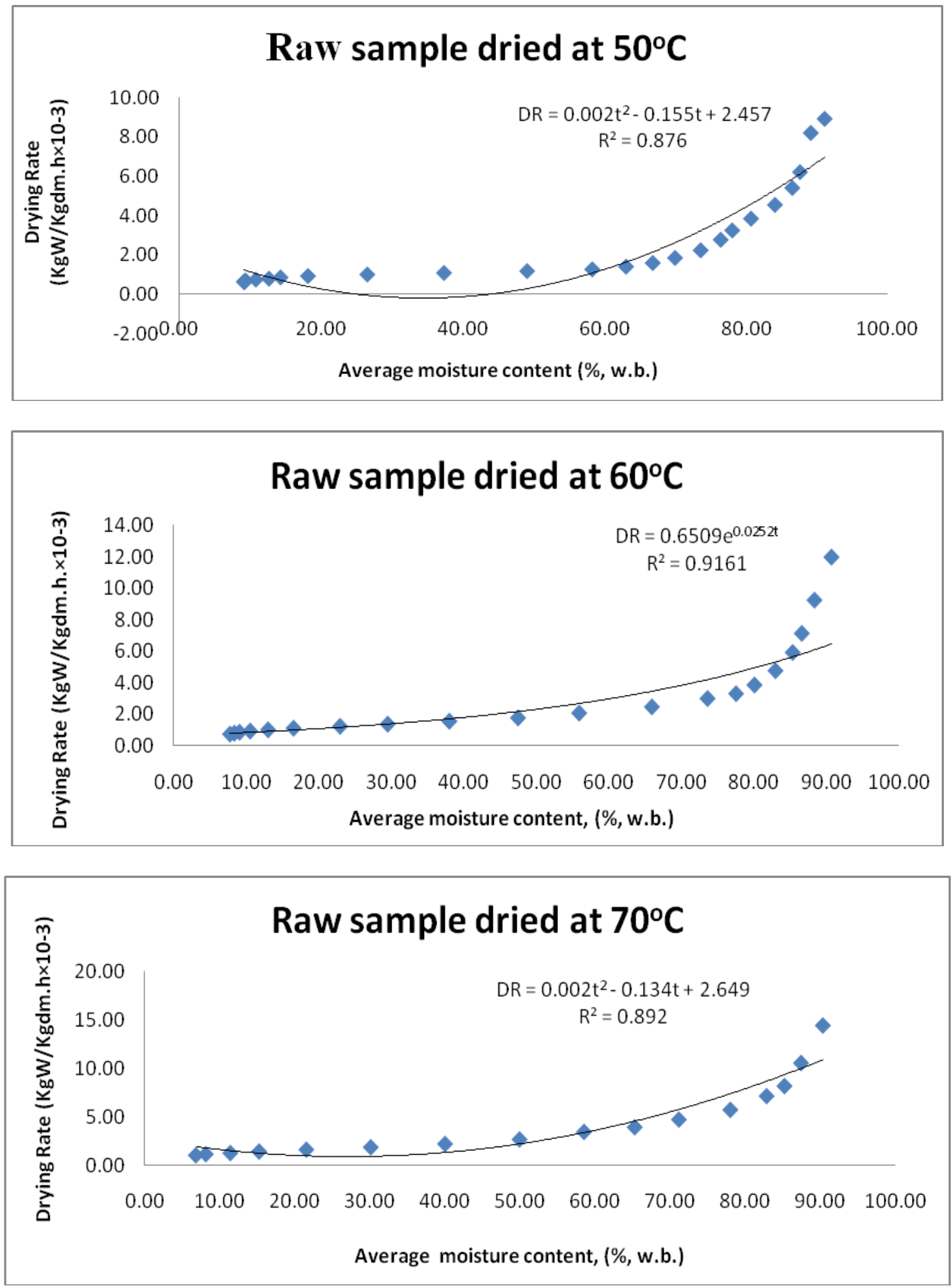
Fig.3 Variation in drying rate of blanched pointed Gourd discs with average moisture content $(\%$, w.b. $)$ at different drying air temperatures
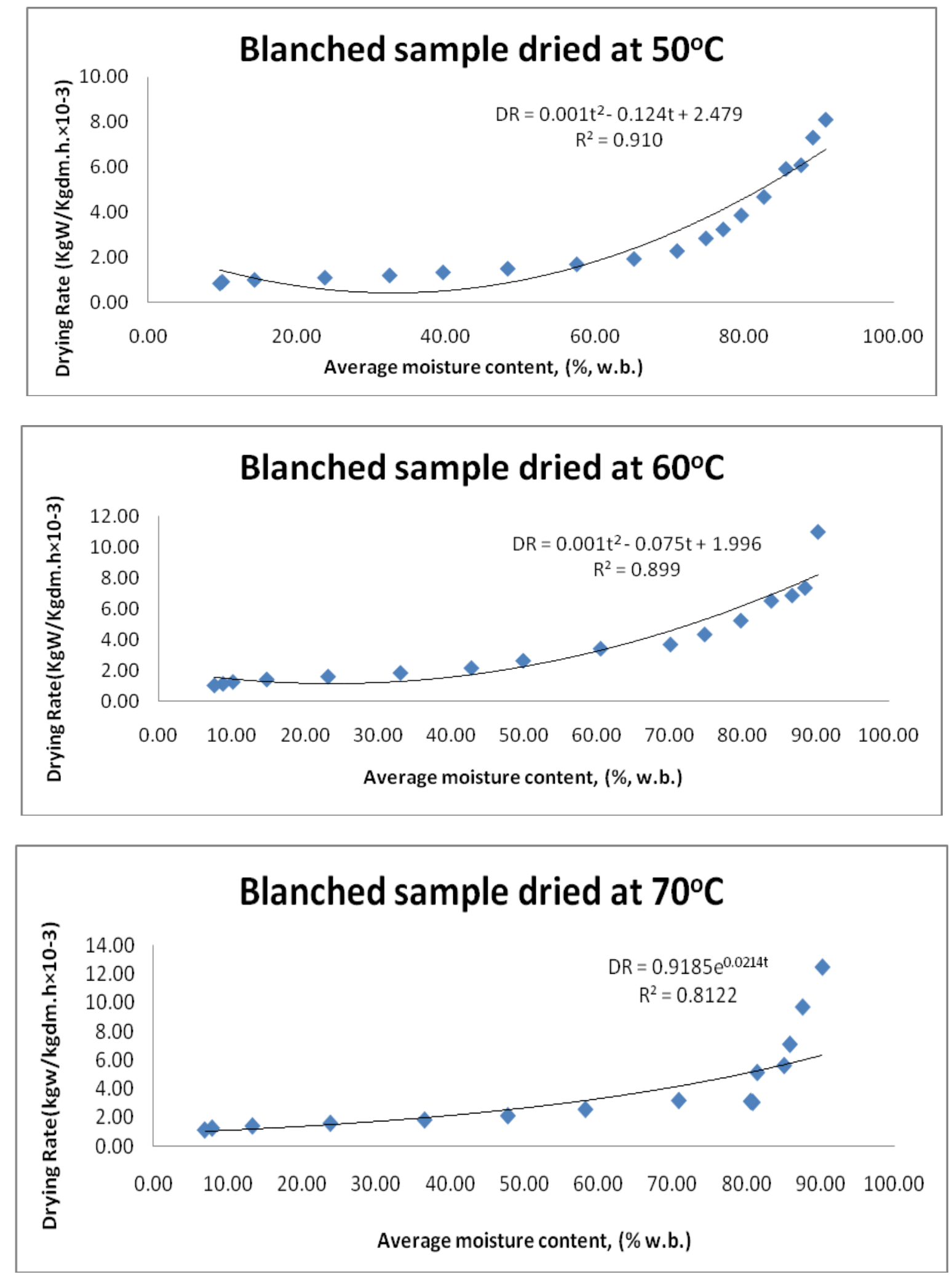
Fig.4 Variation in drying rate of osmosed pointed gourd discs with average moisture content (\%, w.b.) at different drying air temperatures
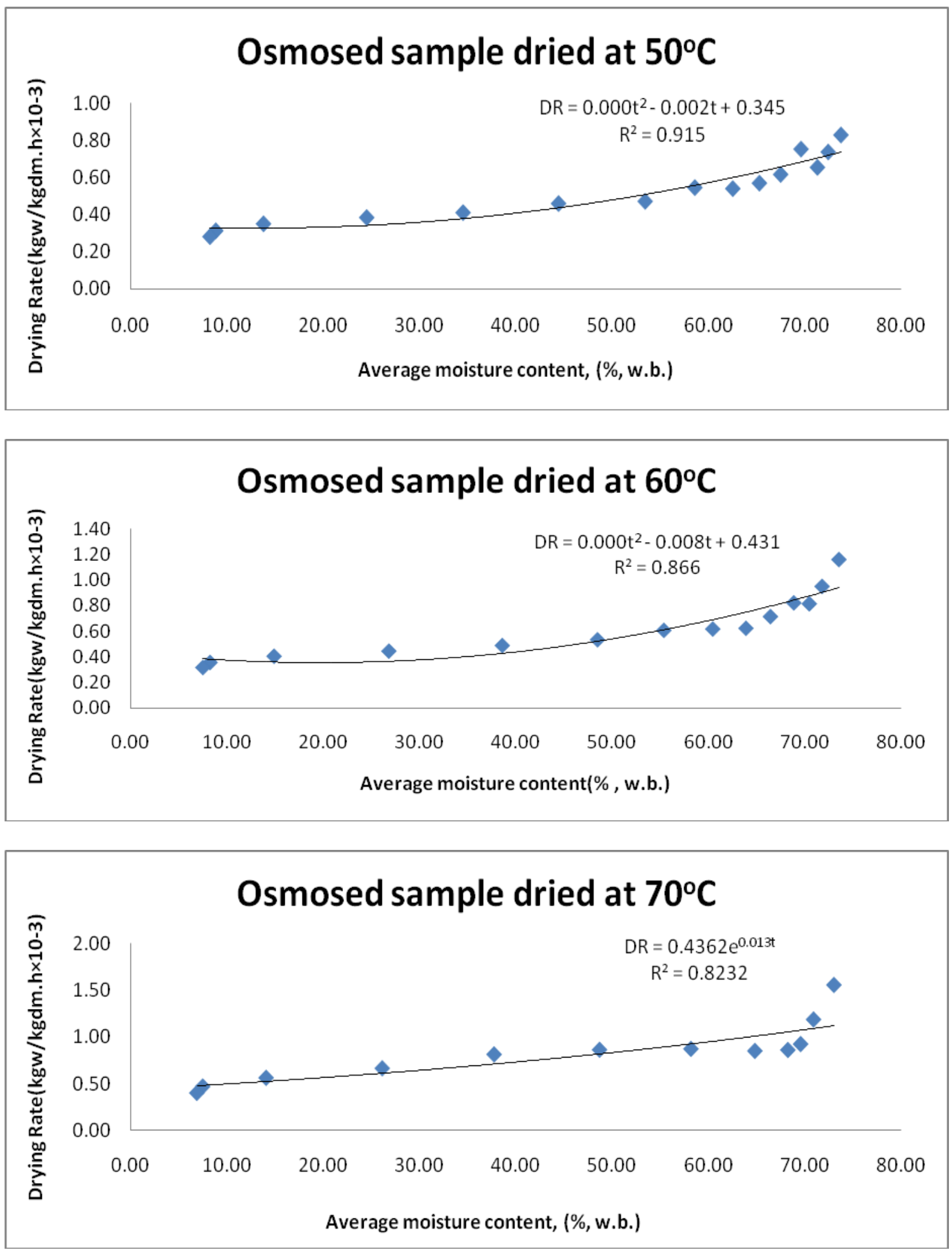
Table.1 Variation in moisture content (\% w.b.) of pointed gourd samples during tray drying for different drying air temperatures

\begin{tabular}{|c|c|c|c|c|c|c|c|c|c|}
\hline \multirow{3}{*}{$\begin{array}{l}\text { Time } \\
\text { (min) }\end{array}$} & \multicolumn{9}{|c|}{ Moisture content (\% w.b.) } \\
\hline & \multicolumn{3}{|c|}{ Raw Samples } & \multicolumn{3}{|c|}{ Blanched Samples } & \multicolumn{3}{|c|}{ Osmosed Samples } \\
\hline & $50^{\circ} \mathrm{C}$ & $60^{\circ} \mathrm{C}$ & $7^{\circ} \mathrm{C}$ & $50^{\circ} \mathrm{C}$ & $60^{\circ} \mathrm{C}$ & ${ }^{70} \mathrm{C}$ & $50^{\circ} \mathrm{C}$ & $60^{\circ} \mathrm{C}$ & $7^{\circ} \mathrm{C}$ \\
\hline 0 & 92 & 92 & 92 & 91.7 & 91.50 & 91.6 & 74.50 & 74.61 & 74.31 \\
\hline 15 & 90.26 & 89.48 & 88.77 & 90.09 & 89.11 & 88.80 & 73.07 & 72.57 & 71.80 \\
\hline 30 & 88.09 & 87.30 & 86.19 & 88.26 & 87.96 & 86.27 & 71.85 & 71.10 & 70.06 \\
\hline 45 & 87.24 & 86.00 & 84.35 & 86.91 & 85.56 & 85.35 & 70.84 & 69.91 & 69.13 \\
\hline 60 & 85.89 & 84.76 & 81.43 & 84.21 & 82.26 & 84.73 & 68.43 & 67.87 & 67.42 \\
\hline 90 & 82.36 & 81.25 & 74.69 & 81.00 & 77.18 & 78.09 & 66.61 & 65.06 & 62.29 \\
\hline 120 & 79.12 & 78.95 & 67.72 & 78.12 & 72.35 & 83.52 & 64.03 & 62.78 & 54.13 \\
\hline 150 & 77.05 & 76.18 & 62.91 & 76.15 & 67.78 & 77.53 & 61.07 & 58.15 & 43.31 \\
\hline 180 & 75.88 & 71.09 & 54.21 & 73.50 & 53.19 & 64.16 & 56.15 & 52.62 & 32.255 \\
\hline 240 & 71.41 & 60.80 & 45.72 & 68.41 & 46.55 & 52.37 & 50.75 & 44.36 & 20.07 \\
\hline 300 & 68.65 & 51.02 & 34.35 & 61.94 & 38.97 & 43.24 & 38.14 & 32.82 & 8.14 \\
\hline 360 & 65.12 & 43.91 & 25.92 & 53.05 & 27.07 & 29.94 & 30.92 & 20.79 & 6.91 \\
\hline 420 & 61.09 & 32.07 & 17.18 & 43.41 & 19.13 & 17.84 & 18.13 & 8.95 & 6.91 \\
\hline 480 & 55.58 & 26.88 & 13.33 & 35.69 & 10.22 & 8.94 & 9.46 & 7.47 & \\
\hline 540 & 42.72 & 18.91 & 9.49 & 29.09 & 9.87 & 6.96 & 8.24 & 7.47 & \\
\hline 600 & 32.11 & 14.06 & 6.82 & 18.28 & 7.50 & 6.96 & 8.24 & & \\
\hline 660 & 21.06 & 11.85 & 6.82 & 10.23 & 7.50 & & & & \\
\hline 720 & 15.39 & 9.11 & & 9.62 & & & & & \\
\hline 780 & 13.29 & 8.91 & & 9.62 & & & & & \\
\hline 840 & 12.14 & 7.70 & & & & & & & \\
\hline 900 & 9.58 & 7.70 & & & & & & & \\
\hline 960 & 9.23 & & & & & & & & \\
\hline 1020 & 9.21 & & & & & & & & \\
\hline 1080 & 9.21 & & & & & & & & \\
\hline
\end{tabular}


Table.2 Drying rate of pointed gourd samples during tray drying at different air temperatures

\begin{tabular}{|c|c|c|c|c|c|c|c|c|c|}
\hline \multirow{3}{*}{$\begin{array}{l}\text { Time } \\
(\mathrm{min})\end{array}$} & \multicolumn{9}{|c|}{ Drying Rate, $\left(\mathrm{kgw} / \mathrm{kgdm} . \mathrm{h} \times 10^{-3}\right)$} \\
\hline & \multicolumn{3}{|c|}{$50^{\circ} \mathrm{C}$} & \multicolumn{3}{|c|}{$60^{\circ} \mathrm{C}$} & \multicolumn{3}{|c|}{$70^{\circ} \mathrm{C}$} \\
\hline & Raw & Blanched & Osmosed & Raw & Blanched & Osmosed & Raw & Blanched & Osmosed \\
\hline \multicolumn{10}{|c|}{ (1) } \\
\hline 15 & 8.91 & 8.10 & 0.82 & 11.97 & 10.97 & 1.15 & 14.36 & 12.47 & 1.55 \\
\hline 30 & 8.20 & 7.31 & 0.73 & 9.24 & 7.34 & 0.94 & 10.51 & 9.69 & 1.18 \\
\hline 45 & 6.21 & 6.09 & 0.65 & 7.14 & 6.85 & 0.81 & 8.14 & 7.10 & 0.92 \\
\hline 60 & 5.41 & 5.92 & 0.75 & 5.93 & 6.50 & 0.82 & 7.11 & 5.62 & 0.86 \\
\hline 90 & 4.55 & 4.69 & 0.61 & 4.77 & 5.22 & 0.71 & 5.69 & 5.13 & 0.85 \\
\hline 120 & 3.85 & 3.87 & 0.57 & 3.87 & 4.32 & 0.62 & 4.70 & 3.06 & 0.87 \\
\hline 150 & 3.25 & 3.25 & 0.54 & 3.32 & 3.680 & 0.61 & 3.92 & 3.13 & 0.86 \\
\hline 180 & 2.78 & 2.86 & 0.54 & 3.01 & 3.41 & 0.60 & 3.43 & 3.18 & 0.81 \\
\hline 240 & 2.25 & 2.30 & 0.47 & 2.48 & 2.62 & 0.53 & 2.66 & 2.57 & 0.66 \\
\hline 300 & 1.86 & 1.95 & 0.46 & 2.09 & 2.15 & 0.48 & 2.19 & 2.12 & 0.56 \\
\hline 360 & 1.60 & 1.71 & 0.41 & 1.78 & 1.84 & 0.44 & 1.85 & 1.83 & 0.47 \\
\hline 420 & 1.41 & 1.52 & 0.38 & 1.57 & 1.59 & 0.40 & 1.61 & 1.60 & 0.40 \\
\hline 480 & 1.28 & 1.36 & 0.35 & 1.39 & 1.41 & 0.35 & 1.41 & 1.41 & \\
\hline 540 & 1.19 & 1.22 & 0.31 & 1.25 & 1.25 & 0.31 & 1.26 & 1.26 & \\
\hline 600 & 1.10 & 1.12 & 0.28 & 1.13 & 1.13 & & 1.14 & 1.13 & \\
\hline 660 & 1.02 & 1.03 & & 1.03 & 1.03 & & 1.03 & & \\
\hline 720 & 0.94 & 0.94 & & 0.94 & & & & & \\
\hline 780 & 0.87 & 0.87 & & 0.87 & & & & & \\
\hline 840 & 0.81 & & & 0.81 & & & & & \\
\hline 900 & 0.75 & & & 0.76 & & & & & \\
\hline 960 & 0.71 & & & & & & & & \\
\hline 1020 & 0.67 & & & & & & & & \\
\hline 1080 & 0.63 & & & & & & & & \\
\hline
\end{tabular}

Table.3 Rehydration characteristics of dried pointed gourd discs at different drying air temperatures

\begin{tabular}{|c|c|c|c|c|}
\hline Sample Type & $\begin{array}{c}\text { Drying Air } \\
\text { Temperature }\left({ }^{\mathbf{0}} \mathbf{C}\right)\end{array}$ & $\begin{array}{c}\text { Moisture in Rehydrated } \\
\text { Sample }(\boldsymbol{\%} \mathbf{\%} . \mathbf{b} .)\end{array}$ & $\begin{array}{c}\text { Rehydration } \\
\text { ratio }\end{array}$ & $\begin{array}{c}\text { Coefficient of } \\
\text { Rehydration }\end{array}$ \\
\hline Raw & 50 & 88.45 & 3.68 & 0.324 \\
\hline Blanched & 50 & 88.56 & 4.23 & 0.374 \\
\hline Osmosed & 50 & 90.06 & 5.12 & 0.446 \\
\hline Raw & 60 & 87.92 & 3.54 & 0.306 \\
\hline Blanched & 60 & 88.60 & 4.06 & 0.351 \\
\hline Osmosed & 60 & 89.97 & 4.79 & 0.414 \\
\hline Raw & 70 & 86.64 & 3.41 & 0.292 \\
\hline Blanched & 70 & 87.43 & 3.87 & 0.332 \\
\hline Osmosed & 70 & 88.69 & 4.53 & 0.389 \\
\hline
\end{tabular}




\section{Rehydration characteristics}

The rehydration ratio of the samples dried at $50^{\circ} \mathrm{C}$ was found to be $3.68,4.23$ and 5.12 for raw, blanched and osmosed samples, respectively. Rehydration ratio (5.12) and coefficient of rehydration (0.446) were found the highest for osmosed pointed gourd samples dried at $50^{\circ} \mathrm{C}$ as given in Table 3 .

The coefficient of rehydration of sample dried at $50^{\circ} \mathrm{C}$ were found to be $0.324,0.374$ and 0.446 for raw, blanched and osmosed samples, respectively whereas it was found to be $0.306,0.351$ and 0.414 at $60^{\circ} \mathrm{C}$. The similar trend of result for rehydration characteristics has been reported in the study carried out by Sharma and Shrivastava (2017).

Drying of osmosed pointed gourd samples at $60^{\circ} \mathrm{C}$ drying air temperature provided shortest drying time to produce best quality dried product as compared to blanched and raw pointed gourd samples.

The drying time of osmosed sample was reduced to 480 minutes as compared to 600 and 840 minutes taken by blanched and raw pointed gourd samples. The value of rehydration ratio and coefficient of rehydration were higher in case of dried osmosed pointed gourd samples at all drying temperatures. The maximum value of rehydration ratio and coefficient of rehydration were 5.12 and 0.446 for samples dried at $50^{\circ} \mathrm{C}$.

\section{References}

Koley, T. K., Asrey, R., Samuel, D. V. K., and Sasikala, C. (2009). Careful handling in pointed gourd after picking pays. Indian Horticulture, 54, 44-45.

Nath, P. and Subramanyam, S. (1972). Pointed gourd can be a popular crop. Indian Horticulture, 17, 20-21.

Ranganna, S. (1986). Hand book of analysis and quality control fruit and vegetable products. Tata McGraw Hill publication Co, New Delhi.

Saha, G, Das, S.N., Khatua D. Fruit and vine rot of pointed gourd-etiology, epidemiology and management. J Mycopathol. 2004; 42:73-81.

Sharma, P.D. and Shrivastava, M. (2017). Drying characteristics and rehydration quality of solar dried pointed gourd (Trichosanthes dioica Roxb.). International Journal of Science, Environment and Technology, Vol.6 (1):684-693.

Som, M. G., Maity, T.K. and Hazra, P. (1993). Pointed gourd (Trichosanthes dioica Roxb.) In Kallo, G. and Bergh, B.O. (Eds.) Genetic improvement of vegetable crops. Pergamon Press, Oxford, New York. pp 251-258.

\section{How to cite this article:}

Nisha Kumari and Pratibha Devi Sharma. 2018. Drying Characteristics of Pointed Gourd Slices. Int.J.Curr.Microbiol.App.Sci. 7(10): 2040-2049. doi: https://doi.org/10.20546/ijcmas.2018.710.236 